\title{
SVERRE FEHNS MUSEUMSTEORI
}

\section{Hans Egede-Nissen}

«Et museum er dansen om 'de døde ting', hvor objektet og dets forhold til den menneskelige bevegelse er det vesentlige - i motsetning til arkitektur hvor mennesket spiller den primære rolle og objektet er sekundært.»'

Dette sier arkitekten Sverre Fehn i en spissformulering. I et vanlig bygg, feks en bolig, tar arkitekten primart hensyn til brukerne. I museet er dette mer eller mindre snudd pa hodet. Her er arkitekturen innrettet på à sikre objektene lengst mulig varighet, ideelt sett permanens. Museet betrakter objektet "nesten som en likeverdig del til mennesket». ${ }^{2}$ Fehn anser denne streben efter a gi objektet udødelighet à vare en folge av vårt frustrerte forhold til døden. Bortfallet av troen på noe hinsidig har efterlatt et vakuum som gjor konfrontasjonen med døden uutholdelig.

Derfor - og dette anser Fehn å vare eksepsjonelt for vår tid-orker vi ikke à bli minnet om døden. Bunnen har, om man vil, falt ut av markedet for memento mori-fremstillingene. Tvert imot forsoker vi konsekvent a holde alt det som minner oss om døden på armlengdes avstand. ${ }^{3}$ Dermed blir tingene, hvis opplosning ville bragt tanken hen $p a$ vair egen timelighet, anbragt på museer hvor man forsøker à gi dem evig liv. Museene blir liggende "som store kuvøser i landskapene»"

Fehn sammenholder denne fornektelsen av opphøret med måten man i det gamle Egypt - og hertillands i norrøn tid - overgav gjenstander til dødsriket, og finner vår adferd å være uttrykk for en "paradoksal fattigdom».

Følgende sitat viser da også at Fehns grunnleggende holdning til museet som fenomen ikke kan oppfattes som direkte bejaende:

Practical research began to dig beneath the surface, and the light of day shone through history. Science took over from passion, and mysticism and respect for the dead were destroyed by the rational viewpoint. Infinity was replaced by finity. The artifacts were spread all over the planet and the museum was born. The conversation with the dark was interrupted.

Det er mot denne bakgrunn og med denne innstilling at Fehn nærmer seg sin oppgave: å bygge om en gammel låve til kulturhistorisk museum. Hans ambisjon er å få «fortiden i tale», noe han mener å kunne oppnå ved å «manifestere nuet». Det er 
76 denne ambisjon - som signaliserer at han er mindre konvensjonell i sin metode enn i sitt forsett - jeg har til hensikt å utrede implikasjonene av i det følgende.

Jeg finner det naturlig innledningsvis å redegjøre for Fehns spekulasjoner omkring objektets ontologi, for så ved en gjennomgang av hans museumsoppfatning å komme inn på hans utstillingsmetodikk.

\section{OBJEKTETS ONTOLOGI}

I artikkelen "The order of display» ${ }^{6}$ trekker Fehn opp hovedlinjene i sin forståelse av objektet, han kritiserer museet som institusjon og han skisserer sine egne utstillingsidealer.

Gjennomgangen av objektet begynner med bollen, den hule form, som Fehn betrakter som selve urobjektet. Den gjorde det mulig å magasinere grøden, og man opphevet behovet for alltid å være nær kildene. Den hule form gav frihet - til å foreta reiser, til å tenke, til å skape nye gjenstander: "The bowl is the root of all objects.» ${ }^{7}$

Mennesket skiller seg fra dyrene primært ved å nedfelle erindringen om sin egen eksistens i gjenstander. Noe blir tilbake efter oss, som minner om vår tid på jorden. Blant de objekter som henleder tanken på det indviduelle liv, regner Fehn gravstenen som det ultime: Dens hensikt er eksklusivt å være et minnesmerke over et individ. Samtidig er den - i egenskap av å være gravens objekt - et symbol på døden.

I spennet mellom disse ytterpunkter for menneskelig skapelse finner vi portrettet. Fehn betegner det som «the link between man and his image, a personality on dis- play». ${ }^{8}$ Portrettet tillot den avbildede å føre en dialog med sitt eget bilde. "The artist was the family doctor of thought,» sier Fehn. Som en god huslege kom han folk til unnsetning i hjemmet. Den åndelige stimulus han efterlot i maleriets form, ble gjerne hengende i rommet hvor det ble til.

Its mood was part of the total expression. The creation was influenced by the room, and when finished it was situated in the context to which it belonged. The fixed location permitted the recognition of place through its objects. ${ }^{9}$

Ved den portrettertes død opphørte dialogen mellom ham og objektet. Men objektet vedble å samtale med rommet, i kraft av å befinne seg i samme lys som det var malt:

If the painting is strong enough, it will assert its existence independent of its original owner. Confident in its own magic, the object will continue through time. Its strength will pursue a new existence revitalizing the instant of the viewer..$^{10}$

Fehn setter et skarpt skille ved atelierenes oppkomst. Da opphører sammenfallet mellom tilblivelsessted og opphengslokale. Bildet var en del av atelieret der det ble til, men forbindelsen ble brutt straks det var ferdig. Maleriet ble henvist til en omflakkende tilværelse, til stadige konfrontasjoner med den ytre verden. Dets situasjon ble nomadisk.

Antagelig tenker Fehn ikke bare på maleriet. Enhver gjenstand som rykkes ut av sin opprinnelige kontekst kommer til å flyte fritt rundt $\mathrm{i}$ tidens og rommets dimensjoner, inntil det eventuelt finner rotfeste i en ny. 


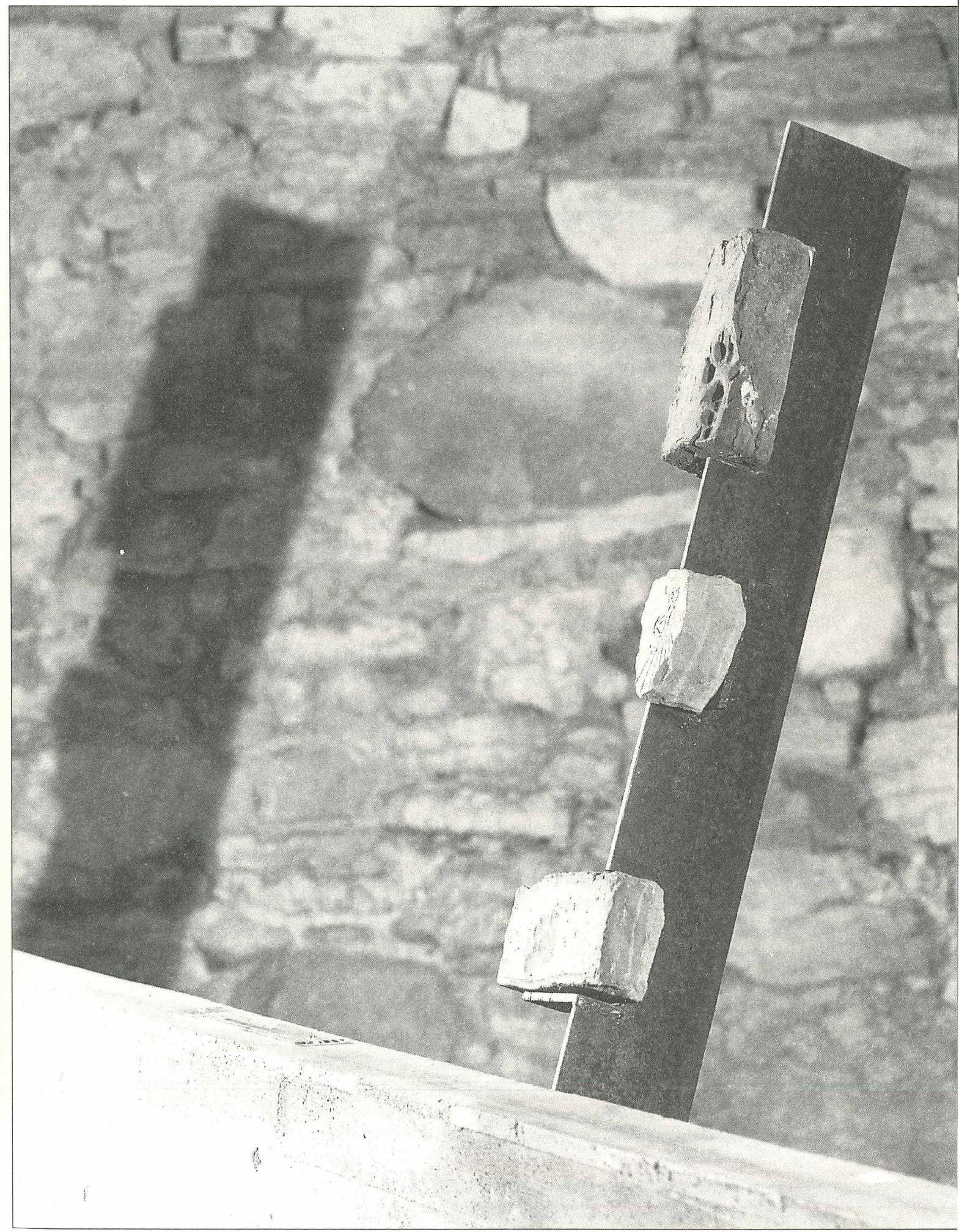

Fra utstillingen Hedmarksmuseet, Domkirkeodden Hamar. Tre teglstener med avtrykk.

Foto: Knut E. Fønstelien. 


\section{HVA GJØR MUSEET MED OBJEKTET?}

Vi ser altså hvorledes Fehn mener objektet står i det han kaller en «dialog» med sin opprinnelige kontekst. Det som kjennetegner museale objekter er at de er rykket bort fra denne dialogen, på samme måte som det atelier-tilblevne maleri: "The studio and the museum become equivalent.» ${ }^{11}$ Hjemløse i tid og rom er objektene tvunget til konfrontasjon med en verden de er fremmede for. I et sitat beskriver Fehn det totalt fremmedgjorte objekt, slik det står for ham som utgangsmaterialet for utstillingen på Høvikodden i 1985:

Finnes der en større ensomhet enn 11 trekasser fra Kina med bandasjerte terracottafigurer innspent i jernstativ, løsrevet fra en hær på 7000 soldater bestemt for en reise med sin keiser Qin Shihuang inn $\mathrm{i}$ evigheten. ${ }^{12}$

Det naturlige hvilested for en fremmedgjort gjenstand er selvfølgelig museet. Hit skulle gjenstandene kunne komme med sin alderdom, sin skrøpelighet og uanvendelighet, og bli hedret nettopp for disse kvaliteter. Men når "... the museum is only a place of storage, the objects are dishonored.»13 $\mathrm{Og}$ iflg. Fehn er det i mange tilfeller nettopp dette som skjer, uaktet hvilken utstillingsform man faller ned på. Fehn regner med to hovedtyper: den litterære, som forsøker å rekonstruere objektets opprinnelige sammenheng eller illudere tidsmaskin, og den som ikke gir seg inn på rekonstruksjonsretorikk, men forholder seg til gjenstanden primært som et materielt faktum. ${ }^{14}$ I sin omtale av middelalderutstillingen på Høvikodden i 1975 feller Fehn en hård dom over førstnevnte alternativ:
Utstilling av gamle ting vil være en presentasjon av objekter som er bragt ut av sin egentlige sammenheng. Deres opprinnelige plassering i tid og rom er forrykket, og problemet blir følgende: skal man skape illusjon av en fortid?

Selv om det ville være mulig å rekonstruere et kirkerom etter nøyaktige tegninger, anvende de samme materialer og plassere det på samme tomt, så ville menneskene som befolker miljøet rundt objektene være anderledes, bære andre klær og bevege seg $i$ en annen rytme, føre et annet sprog etc.

Erkjenner man dette problem, og nekter å gi seg ut på noen som helst form for miljøbløff, står man alene med kunstverket, - som må få anledning til å begynne et nytt liv og en ny dialog med dagens mennesker. ${ }^{15}$

Men også den «illitterære» utstillingsmetodikken har sine fallgruber, fordi den altfor lett underkjenner gjenstandenes individualitet, behandler dem som om alle var like. Museet blir da en «skuff» ${ }^{16}$ som undergraver det partikulære ved hvert enkelt objekt. Dermed oppstår heller ikke det som Fehn ser som enhver utstillings mest fortjenstfulle hensikt: å få istand «a vital confrontation between the person viewing and the object viewed ${ }^{17}$; a berøre eller aktivisere betrakteren - gjenstanden blir simpelthen for likegyldig. Først når det skjer at "the dialogue between the curator and his possession can be visualized through the architect's projection,» gjør objektet krav på betrakteren. "In this situation the viewer becomes involved with the 'place' of the object.»

Når Fehn her benytter ordet "place», viser det utover de rent geografiske koordinater. Bruken må sees i sammenheng med den forbindelse han mener består mellom maleriet og det rom der det ble til. Den vellykkede utstilling vil kjenne- 
tegnes ved at objektet forlenes med et nærvær motsvarende det ikke-nomadiske maleri, med andre ord blir hjemmehørende $\mathrm{i}$ både tidens og rommets dimensjoner. (Fehn sier da også: «For the object to survive it must find its place in time [forf. uth.].. ${ }^{18}$ ) Monteren blir da noe mer enn en likegyldig ramme omkring objektet, den danner et substitutt til gjenstandens opprinnelige sted. Og med gjenstanden i denne posisjon oppstår grunnlaget for Fehns «vitale konfrontasjon».

\section{FEHNS UTSTILLINGSMETODIKK}

Ser man nærmere på hvordan Fehn opererer for å få istand denne konfrontasjonen, kan det se ut som om følgende sitat fra et intervju med Ragnar Pedersen gir et utgangspunkt for å forstå hans ambisjon:

[...] man å få dem [gjenstandene] visuelt klargjort. [...] [Man må] ta objektet som det er og presentere det på den beste måten, slik at gjenstandenes form forteller historien. ${ }^{19}$

Dette sitatet rommer to vesentlige uklarheter. Hva inebærer det å presentere objektet "på den beste måten»; og hvilken "historie» er det Fehn tiltror gjenstanden å kunne fortelle? Først til «den beste måten». Til Per Olaf Fjeld sier Fehn:

To exhibit an object correctly one must be the object. The object has to reveal itself to the curator. $\mathrm{He}$ must open up his being to the loneliness of a dialogue and transfer his spirit into the object. Likewise the curator must resituate the object in a context in such a way that it will reveal its form. [...] The key to the art of display resides in the architect imagining himself as an object..$^{20}$
I et intervju går han nærmere inn på dette:

[gjenstanden] har vært en ring på din hånd, den har vært en diamant som har reflektert farven av dine øyne, en klokke som glir opp og ned av din lomme, et bestikk du har hatt et forhold til med dine hender og krusifikset du har tilbedt. [...] Du må falle helt inn i selve gjenstandens fysiske verden. Skjeen er så og så stor, hvordan skal den leve alene uten hånden som løfter den fra suppen. [...] Du skal altså drømme deg inn i den situasjonen. Da må gjenstanden ha et rom eller et forhold i et monter [...]. Du skifter ut deg selv med gjenstanden, det er den som skal bestemme hvilket rom den skal fá bo i. [forf. uth. $]^{21}$

Den praktiske delen av utstillingshandlingen utdypes i følgende sitat:

Gjenstanden må jo ha et rom den kan få plass i, eller finne sitt uttrykk eller bli vakker i.[...] Det gjelder å finne gjenstandens dynamikk, den har i seg selv et uttrykk som du må prøve å lage et rom rundt. Og det gjelder å finne gjenstandens historie: Som jeg sa om perlen som ligger på kvinnens bryst, hvordan skal den utstilles; kan den ligge på et bord hvor man har slaktet et dyr; er det der den arbeider best, eller i et rom med gullvegger; alt det der er det masse å gjøre med. Når den ikke har kvinnen med de øynene som den er kjøpt til eller funnet til, det er der jobben ligger. ${ }^{22}$

Vi finner altså at Fehn forfekter utstillingsarkitektens oppgave som en type forstillingskunst. Videre har vi sett at han avsverger tanken om å gjenskape fortiden slik den «virkelig var». Historisk korrekthet fremstår som en umulig ambisjon, idet den forestilling som skapes i betrakterens bevissthet - hvor eksakt man enn rekonstruerer - ikke under noen omstendighet 
80 vil stemme overens med den historiske aktørs erfaring.

Men når den faktiske historiske erfaring ikke lar seg befordre; hvilken "historie» er det da Fehn er ute etter å implantere i betrakterens hode? Jeg tror Fehn betrakter objektet ikke så meget med historikerens eller etnologens blikk, som med det blikk den pasjonerte kirkegårdsvandrer anlegger på gamle gravskrifter. Han søker å møte det med undring, fantasi og innlevelse snarere enn med absolutte kunnskaper. Det virker som om Fehn ikke betrakter gjenstandene så meget som innfallsporter til historien med stor $\mathrm{H}$, som - med Jan Brochmanns ord - til de mange «historier uten den minste konsesjon til historisering ${ }^{23}$. Derfor tror jeg ikke at Fehn bokstavelig hevder at gjenstanden «forteller» en entydig "historie». For Fehn er «historien» det "noe» som blir til i betrakterens hode ved synet av gjenstanden, med utgangspunkt $\mathrm{i}$ vedkommendes forutsetninger. Han hevder da også: «Objektet [...] må stå i en visuell kontekst slik at du til enhver tid kan bygge opp din egen [forf. uth.] historie rundt det. $\aleph^{24}$

Når det nå engang er skjedd at gjenstanden er blitt et fragment, bør man unngå å late som om så ikke er skjedd. Istedet bør man gjøre det beste ut av situasjonen, nemlig å la gjenstanden «begynne et nytt liv og en ny dialog med dagens mennesker». For å oppnå dette griper Fehn fatt $\mathrm{i}$ det uomtvistelige ved gjenstanden - dens form, dens materialkarakter, dens estetikk - og overlater til betrakteren å arbeide videre med det observerbare i fantasien, bruke det som utgangspunkt for fabule- ring, gjetninger, undersøkelser. For Fehn har denne typen aktivitet en egenverdi, hvor uvitenskapelige historiene som fremkommer enn måtte være:

Likegyldigheten til fortidsminnene er det verste, aktivitet er det som må tilstrebes. Dermed får du en dialog i gang -, noe du må ta stilling til. Du kommer $\mathrm{i}$ en posisjon, blir et levende menneske av det. ${ }^{25}$

Hvilken verdi denne fabulering har for Fehn, kommer tydelig frem $i$ et annet sitat, hentet fra Fehns hilsen til Jan Groth:

Når jeg er i London besøker jeg hver gang British Museum og den egyptiske samling. Det morer meg å tegne av hieroglyffene, og min private tydning av disse tegn fører inn i en verden som er min egen.

Men ved mitt siste besøk i sommer kom jeg til å lese om hieroglyffenes tydning for ca. 150 år siden, de forskjellige tegnenes mening. Min egyptiske verden forsvant og jeg gikk tom ut av museets port. ${ }^{26}$

Likevel synes det hevet over tvil at Fehn ikke ufravikelig fastholder prinsippet om å forkaste en gjenskapning av tapte kontekster. På Høvikodden i $1985^{27}$ stilte han ut elleve terracottafigurer hentet fra en kinesisk keisergrav. Her gjenskapte han illusjonen av den enorme "hæren» på omkring 7000 soldater ved å anbringe figurene mellom speilsøyler stillet overfor hverandre, så rekken av terracotta-soldater ble reflektert ad infinitum. Selvfølgelig er denne illusjonen meget abstrakt og også lettgjennomskuelig; alle kan se at fantomene i speilflatene kun er refleksjoner - men ikke desto mindre rekonstruerer monteringen et vesentlig aspekt ved den fortidige kon- 

Hans Egede Nissen

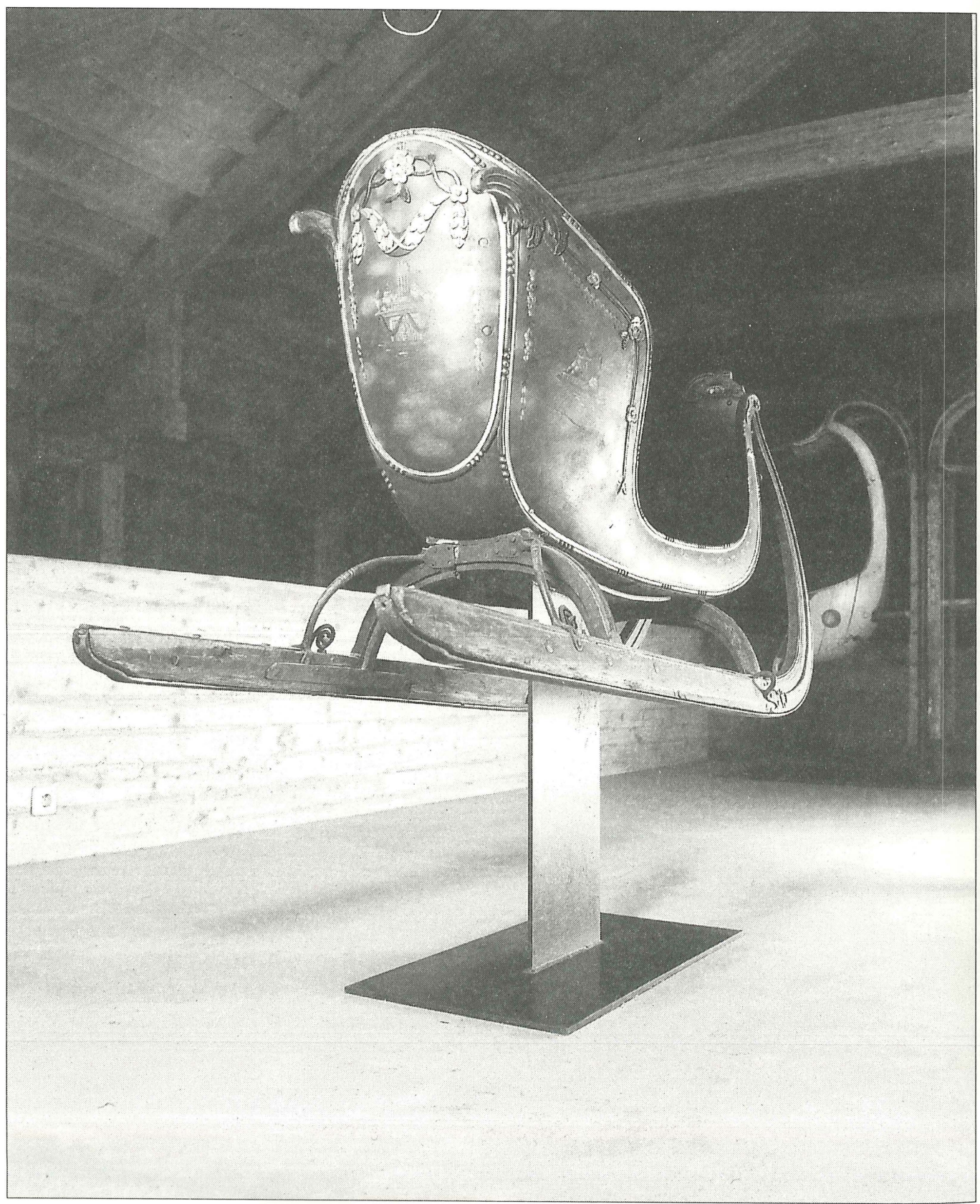

Fra utstillingen Hedmarksmuseet, Domkirkeodden Hamar. Spisslede fra Blystad, Vang ca. 1790. Foto: Knut E. Fonstelien. 
teksten: hærens velde. Belysningen i rommet var også sterkt dempet, slik at man kunne få følelsen av å gå inn i en grav som var iferd med å åpnes. Jeg har også vært inne på enkelte eksempler i samme kategori under gjennomgangen av utstillingene i Storhamarlåven: iøynefallende er hedmarksarden, som - til tross for at den ikke holdes $\mathrm{i}$ hendene på en voksdukke får tydeliggjort sin fortidige funksjon gjennom monteringen. Med dette sprenger Fehn sitt eget forsett om å la «gjenstandenes form fortelle historien", om man skal oppfatte dette bokstavelig. Det er også åpenbart at han sommetider betoner mindre håndgripelige kvaliteter ved gjenstandene: Den mystiske aura som omgir den såkalte djevelens finger er utvilsomt bevisst aksentuert, og det er derfor ikke en nøytral eksponering som finner sted. Videre er Fehn glad for at gjenstandene kan stilles ut i det samme regionale lyset de ble til under ${ }^{28}$ : Det opphever noe av fremmedgjøringen, men må også anses som et naturgitt bidrag til gjenskapning av den tapte konteksten.

Det Fehn gjør er høyst betegnende å sette gjenstanden «i scene», noe han jo også betrakter som sin oppgave. ${ }^{29}$ Han går imidlertid lenger enn à anvende regiens virkemidler til å anskueliggjøre dens form, og beveger seg dermed på utsiden av rammene for sin ambisjon om å «la gjenstandens form fortelle historien".

Fehns «renskårne» ambisjon om å tilgjengeliggjøre gjenstanden visuelt er derfor bare tilsynelatende. I virkeligheten stiller han seg mellom objektet og betrakteren og gir mer eller mindre tydelige anvisninger om hvilke historier objektet skal innskrives i. Fehn gir seg på ingen måte inn på noen spekulativ rekonstruksjonsre- torikk, men han overskrider sitt eget forsett $i$ en retning som neppe fristiller tilskuerens assosiative apparat. Mathilde Petri reiser da også spørsmålet:

What is questionable in his set-ups is the level of interpretation of the objects. When does it become so personal that it loses general interest? ? $^{30}$

Fehn søker å «manifestere nuet» for å «få fortiden i tale». I forbindelse med utstillingene såvel som arkitekturen innebærer dette som vi har sett å ikke fornekte sin egen tids uttrykk, materialer og konstruksjonsteknikker. Fehn skaper da også ganske konsekvent monteringer som er samtidige i sitt uttrykk, det er aldri problematisk å skjelne montering fra gjenstand. Ved et par anledninger ser vi ham dog benytte materialer som danner et apropos til angjeldende objekt. Det gjelder bl.a. de gammelmodige lærstroppene som benyttes til å feste en rekke gjenstander i folkemuseumsfløyen, og som for ihvertfall sålaupens vedkommende assosierer direkte til bruksmåten. Her synes det som om Fehn beveger seg på grensen mellom rekonstruksjon og konstruktivitet: Han benytter et materiale og en teknikk som rent teknologisk forlengst er utdatert - om enn fortsatt fullt anvendelig - «offisielt» for å betone festemåten, men kanskje vel så meget for å antyde noe om gjenstandens opprinnelige kontekst. Det ville sikkert vært mulig å lage et minst like forsvarlig feste med mer tidsmessige materialer, uten å fravike prinsippet om konstruksjonens visuelle tilgjengelighet. ${ }^{31}$ Når så ikke skjer, bestyrker det teorien om at Fehn ikke helt ut tar konsekvensen av sin kongstanke: å «manifestere nuet». 


\section{FEHNS POSISJON}

I Italia, landet det det moderne utstillingsdesignet har et av sine fremste utspring, var modernismen særlig uforsonlig $\mathrm{i}$ sitt forhold til historie og tradisjoner. I 1909 kunne futuristen Filippo Marinetti (1876-1944) skrive: "A roaring car, sounding like gunfire as it drives along, is more beautiful than the Nike of Samothrace. " $^{32}$ Modernismen opponerte mot tradisjonen; den motsatte seg den kultur som hvilte på antikken. Marinetti ønsket å befri Italia "for dets gangrene av professorer, arkeologer, ciceroner og antikvarer. Alt for lenge har landet vært et gigantisk bruktmarked. Alle disse museene som dekker det med like så mange gravplasser må vi bli kvitt. [...] Frem med de velsignede pyromanene! Grav nye løp for kanalene og sett museene under vann! [...] Grip hakke og hammer! Riv grunnen bort under de ærverdige byene! ${ }^{33}$

Marinetti står som selve erkeeksponenten for en rabiat modernisme, en «barnslig lek med noen av modernismens farligste våpen ${ }^{34}$, og han blir da også en vektig premissleverandør til fascismen. ${ }^{35}$ Det ekstreme ligger selvfølgelig i den kompromissløse forakten for tradisjon og historie, den ukritiske begeistringen for alt det nye. Naturligvis er det misvisende å identifisere hans holdninger altfor entydig med modernismen. ${ }^{36}$ Allikevel kan man ikke unngå å legge merke til at noe av Marinettis tankegods, om enn i en vesentlig moderert og mere salonfähig form, er blitt en integrerende del av den modernisme som har satt sitt preg på det tyvende århundre. Man må kunne betrakte Marinetti som en ytterliggående, men i en viss forstand representativ målbærer av modernismens uomgjengelige krav om en fullstendig revisjon, om å starte historien på nytt.

Det er derfor iøynefallende, og ikke helt uproblematisk, når erklærte modernister som Carlo Scarpa og Franco Albini relativt kort tid efter at Marinetti hadde lagt ned sin penn, tar til å befatte seg med kulturhistoriske museer; den konservative samfunnsinstitusjon par excellence. Man skulle tro at dette innebar å gå på akkord med helt grunnleggende prinsipper innenfor den bevegelse man har sine røtter $\mathrm{i}$, og at det samme skulle ha gyldighet for Fehn.

Én mulig årsak tror jeg ligger $i$ at fremveksten av «the Italian School» først og fremst finner sted efter annen verdenskrig, og faller sammen med en generell bestrebelse på å bryte med fascist-tiden. Under fascismen ble museet benyttet i propagandistisk øyemed, til å eksponere statens makt. Man kan antagelig se "the Italian School» bl a som en revolt mot denne maktdemonstrasjonen. Skolen ble til ikke primært som en reaksjon mot museet som konserverende samfunnsinstitusjon, men som en reaksjon mot fascistenes anvendelse av det. Med andre ord rettes reaksjonen snarere mot måten å eksponere objektene på, enn mot det å utstille objekter. Det man ønsket var å skape et demokratisk museum til forskjell fra et propagandistisk; ikke revoltere mot museet som sådant.

For Scarpas del vil jeg tro at hans oppvekst i den "passatistiske»" ${ }^{37}$ byen Venezia, kan ha utvirket en personlig uvilje mot modernismens fortidsdestruktive tendenser. Scarpa fikk tidlig et forhold til historien, ikke minst ved à bo i dens manifestasjoner. Richard Murphy skriver da også: 
Scarpa was no modernist turning his back on history; rather he wanted to build on and construct within it. Like [William] Morris he was determined to be a continuer of history, and in a rare moment of introspection Scarpa spoke of his «immense desire to belong inside a tradition but without having capitals and columns because you just can't do them any more... How can one make certain statements if one isn't educated", educated, as Foscolo says, "to histories" if there is no education in the things of the past? ${ }^{38}$

Jeg våger å påstå at man finner igjen meget av den samme holdningen hos Sverre Fehn, som både betrakter historien med adskillig hengivenhet og $\mathrm{i}$ en viss forstand tror på muligheten av å komme den i møte. Hans ønske om å være en «continuer of history» kommer ikke minst til uttrykk i måten han anbringer sine addisjoner over den eksisterende struktur, som en tilføyelse til historien. Det er dog enkelte trekk som hos Fehn tyder på en mer rendyrket modernistisk holdning: ikke minst at han oftere gjør sine egne installasjoner til kontrapunkter, at han benytter et smalere spekter av materialer, at han i det hele tatt synes mindre opptatt av å harmonisere sine egne installasjoner med det bestående enn Scarpa, mere opptatt av å «manifestere sitt eget nu» i materielle kontraster. Dette til tross er det såvidt mange fellestrekk i de to arkitektenes tilnærminger at jeg finner det forsvarlig å trekke vidtrekkende paralleller.

I det følgende skal jeg først redegjøre for visse grunntrekk ved det etablerte kulturhistoriske museet. Dernest skal jeg presentere en forfatter som står i skarp opposisjon til dette, og som tar til orde for en museumsmodell som ligger de tidligmodernistiske idealer meget nær: det surrea- listiske museum. Hensikten er å vise hvordan Fehn og the Italian School befinner seg i skjæringspunktet mellom disse posisjoner, med en viss affinitet i begge leire.

\section{MUSEET SOM BEFORDRER AV IDENTITET OG KUNNSKAP}

Utstillingen "Museum Europa»" demonstrerte med til fulle at begrepet museum har utallige konnotasjoner, og at man vanskelig kan betrakte fenomenets skiftende manifestasjoner under en sammenfattende synsvinkel. Ikke ofte er ett begrep satt til å gestalte et såvidt mangetydig fenomen. Ved å snevre det inn til å dreie seg om det kulturhistoriske museum i den forstand vi kjenner det fra vårt eget land, kan det imidlertid være meningsfullt å utdefinere noen felles opphavs- og begrunnelseskriterier. Jeg velger å betrakte museet delvis som resultatet av identitetsbestrebelser; delvis som utkommet av opplysningstradisjonen; delvis som en frukt av den foranderlighet som er moderniteten.

«Museum Europa» tok utgangspunkt i europeernes møter med andre kulturer når det kulturhistoriske museets fremvekst skulle forklares. Arno Victor Nielsen skriver:

Udviklingen af det europæiske musæumsvæsen og dannelsen av en europæisk identitet er i mangt og meget én og samme historie. Det er ikke så mærkeligt, når man tager $\mathrm{i}$ betragtning, at europæerne $\mathrm{i}$ første omgang kom til bevidsthet om sig selv ved at sammenligne seg med «udenomeuropæiske» folk. Dannelsen af en europæisk selvbevidsthet og identitet går faktisk hånd $i$ hånd med opbygningen of gigantiske samlinger af kuriosa og etnografica fra fremmede folkeslag. 
86 Fra og med renæssancen udmærker de europæiske vækstcentre sig ved en tilsyneladende umættelig trang til at indsamle og opmagasinere, registrere og analysere fremmede kulturers materielle udtryksformer. Fra slutningen af 1700-tallet vender denne akkumuleringstrang sig mot europæernes egne efterladenskaber, og Europa og de europeiske nasjonalstater begynder for alvor å udstille deres egen historie. $^{40}$

Gunnar Danbolt redegjør mere spesifikt for museenes betydning $\mathrm{i}$ arbeidet med å bygge opp nasjonale identiteter. ${ }^{41}$ Han viser hvordan det på 1700-tallet etableres en antropologi som bestrider den klassiske humanismens antagelse om en universell fornuft som menneskets adelsmerke, og isteden stiller opp de individuelle følelsene. Dermed forandres også fokus for menneskets streben: Fra å skulle realisere en overindividuell fornuft gjennom å tre inn i rasjonelle, forutbestemte roller, var man nå henvist til å definere sin egen rolle; finne sin individuelle identitet.

Danbolt mener det er en sammenheng mellom dette nye menneskesyn og nasjonsbegrepets fødsel. Han viser til Novalis, som kalte en nasjon for en makroantropos, et menneske i stor målestokk. Denne parallellføring tilsier at nasjonen må ha en identitet som gjør den forskjellig fra andre nasjoner. Hegel myntet i 1793 ordet Volksgeist på denne identiteten. Det som gjorde denne overføring fra subjekt til nasjon mulig, mener Danbolt, var et nytt kultursyn som slo igjennom med kulturfilosofen Herder. Hans sentrale tese var at en kultur oppstod som følge av en kombinasjon av historiske, geografiske og klimatiske forhold. Når disse er forskjellige fra land til land, måtte nasjonalkarakteren nødvendigvis bli individuell: Den enkelte nasjon må ha en identitet.

For Herder kom nasjonalkarakteren klarest til uttrykk i det menneskene skaper i deres materielle såvel som åndelige kultur. Sproget og kunsten ble regnet for de uttrykk hvor den nasjonale identitet var mest iøynefallende.

Men hverken kunsten eller sproget kunne isolert avdekke den nasjonale identitet. «Selvbiografien,» hevder Danbolt, «forteller oss at hvis det enkelte subjekt ønsker å finne frem til seg selv - sin egen identitet - må det gå veien om fortellingen. Bare ved fortolkende å gjenfortelle historien om seg selv, kan man gjøre seg håp om å finne frem til sin identitet og dermed få mulighet til å realisere den.»12 Likeledes kunne man lete frem den nasjonale identitet ved å berette nasjonens historie. Dette ble begrunnelsen for historiefaget som vitenskapelig disiplin: Det skulle produsere de historiene som dekket de unge nasjonenes behov for å få stadfestet sin identitet. Men gjenstandene var også viktige, fordi de gjennom sin faktisitet materialiserte og bekreftet fortellingene historikerne produserte. De fremstod som overbevisende sannhetsvitner for de historiene sproget bar frem.

Fortellingen om nasjonens fortidige liv og fortidens materielle levninger ble de to veiene inn mot den nasjonale karakter. Den naturlige arbeidsdeling ble at universitetet fikk ansvaret for historien, mens museet skulle samle inn og bevare gjenstandene.

Hvilke historier var det så man produserte? De moderne nasjonalstatene samlet ofte vilkårlige konstellasjoner av folkegrupper under nye paraplyer. Behovet for samlingsmerker var stort, og det var derfor 
viktig å fremheve de deler av historien som kunne ha en harmoniserende, overgripende symbolverdi. Hertillands ble den gamle agrarkulturen gjenstand for en nærmest mytologisk dyrkelse. Folkemuseene, hvoriblant Hedmarksmuseets forløper, Oplandenes Folkemuseum, fokuserte på innlandsbygdenes materielle kultur. Med de store vikingskipfunnene kunne de stolte tradisjoner føres enda lengre tilbake, og også kystkulturen ble med et slag forlenet med en gloriøs fortid.

Men årsaken til det kulturhistoriske museets utbredelse ligger også andre steder. Med modernitetens fremvekst gjennomløp de vestlige samfunnene voldsomme endringsprosesser. Dette avstedkom nye muligheter, men efterlot også en følelse av utrygghet og oppløsning: Alt syntes å være gjenstand for forandring. Som en respons på dette oppstod en økende tendens til nostalgi. "Nostalgien,» skriver Arne Lie Christensen, «er det følelsesmessige svaret på det moderne samfunnets iboende konflikter. Nostalgien er et forsøk på kompensasjon for en tapt stabilitet og trygghet.» ${ }^{43}$ Det nostalgiske behov for å holde igjen fortiden ble ivaretatt på flere kanter og på ulike nivåer. Oppgaven ble kanskje tatt mest alvorlig av det kulturhistoriske museet, som ved å gi kunstig åndedrett til utdøende deler av den materielle kulturen har gitt nostalgien adskillig næring.

Disse foranledninger må ikke ses adskilt fra en grunnleggende ambisjon om å formidle faktisk kunnskap, en ambisjon som har ligget i bunnen av det kulturhistoriske museets prosjekt ihvertfall siden opplysningstiden. Som nevnt ble historieproduksjonen i stor grad overlatt til universitetene, men museets siktemål var ikke desto mindre å bibringe den samme historien. Ethvert respektabelt museum har idag dette som et legitimerende motiv bakenom mer emosjonelt appellative, mindre eksplisitt formulerte forehavender. ${ }^{44}$ Men også identitetsbegrunnelsen er fortsatt et viktig argument for museenes opprettholdelse, langt inn i offisiell kulturpolitikk..$^{45}$

Det kulturhistoriske museet skal altså imøtekomme ihvertfall to behov: Det skal utbre faktisk kunnskap samtidig som det skal befordre identitet og tradisjonsbevissthet. Disse behovene ivaretas hovedsaklig av gjenstander: gjennom gjenstandene søker museet å bedre fortidens tilgjengelighet, og derved korte ned avstanden mellom oss og de som engang brukte dem. Slik bidrar museene til å bestyrke vår hjemstavnsfølelse i historien.

\section{DET SURREALISTISKE MUSEUM}

Antropologen, professor Anders Johansen mener museenes dobbelte ambisjon er en umulighet. I to artikler i Samtiden går han kraftig til felts mot det han mener er formidling av en falsk historiebevissthet, og dermed et bidrag til en feilslått fremtidsberedskap. Han oppstiller et alternativ til den tradisjonelle formidling som har adskillig tilfelles med det museet som the Italian School frembringer, og som Fehn må sies å være en viderefører av. Jeg skal i det følgende redegjøre for Johansens argumentasjon, for så å påvise likhetstrekk mellom det museet han beskriver og det museet Fehn skaper.

Johansen betviler ikke at gjenstander kan tjene historieformidlingen - som beskjedne tilskudd til en kunnskap som i det vesentlige bæres av sproget, og som blikkfang og hukommelsesknagger. ${ }^{46}$ Men 
88 de må ikke få tale for seg, slik de gjerne gjør ved norske museer. Han tar for seg et tilfeldig valgt museumsobjekt: en gammel gaffel. Uten videre konstaterer han at skaftet er av ben, at antallet tenner er et annet enn vanlig er idag, osv. Dette er i og for seg genuin historisk kunnskap: En gang ble noen gafler utformet slik. Men megetsigende er det ikke - ikke spesielt interessant heller. At dette er «et redskap til å distansere seg fra maten og apetitten med, som ble tatt i bruk forholdsvis nylig, av de rike og fine, og bare med hensyn på spesielt fettete og klisne stoffer, at gaffelen kom til som ledd $\mathrm{i}$ en bred og langsiktig forfinelsesprosess - eller at det gav anledning til en større skandale da den første gang ble introdusert i Europa og medførte bannlysning for den skyldige» - det hopper utstillingen glatt over. Dermed utelates alt det som gjør tingen til et betydningsfullt utsagn om sin periodes følelsesliv og mentalitet, altså til en virkelig historisk ting.

Slik gaffelen presenteres, bidrar den kun til å bekrefte oss i troen på at det finnes konstanter i menneskers forhold til mat. Dens historiske dimensjoner undergraves.

Johansen vet - til forskjell fra folk flest at han ikke blir fortalt den hele og fulle sannhet, at gjenstanden ler av betrakteren bak en maske av uangripelighet: Tingen fremstår som så uomtvistelig, og derfor innpoder den sine løgner i oss med suverén autoritet. Den forutsetningsløse betrakter går rett i tingenes felle. Man tror seg stillet overfor et konkret, historisk spisebestikk, mens man i virkeligheten innskriver en museumsgjenstand $\mathrm{i}$ en nåtidig kontekst full av betydninger den i en eller annen utstrekning var fremmed for og uforenlig med. Historisk blir gjenstanden kun i den grad de sosiale, kulturelle og psykologiske omstendighetene spesifiseres.

I litteraturen om museer og kulturvern heter det gjerne at «tingene forteller» når gjenstandene slik får slå skrøner i de besøkende. Tingene gir angivelig også anledning til å «oppleve fortiden». Mye av formidlingsvirksomheten i de kulturhistoriske museene sikter mot å "levendegjøre» det forgangne. Billy Ehn går så langt som å betegne museet "en kulissvärld med anspråk på äkthet $»^{47}$ : Man ønsker å skru klokken tilbake og gjenskape den fortidige realitet. Jay Anderson beskriver såkalte levende museer, institusjoner som søker å gjenskape det miljø som gjenstandene engang var en del $a v{ }^{48}$ Illusjonen av tidsreise forsterkes ved at spesielt trenede guider trer inn i roller som forlengst henfarne, og besvarer spørsmål om hvordan det «er» å leve i angjeldende tid.

Anderson mener at levende museer bygges opp av mennesker som kjenner en nostalgisk lengsel mot fortiden og som er nysgjerrige på det daglige livet $\mathrm{i}$ en spesiell periode. De vil leke seg i det allerede avsluttede, som virker tryggere og mer oversiktlig enn nuet. Det levende museet gir de tids-mistilpassede muligheten til i en stakket stund å reinkarneres $\mathrm{i}$ en mer passende tid.

"Men», innvender Anders Johansen, «fortiden kan ikke oppleves. Bare det nåtidige er virkelighet, fortiden er slutt. Hvis en ting eksisterer, er den en nåtidig ting. Den kan være gammel, men dens fortid 


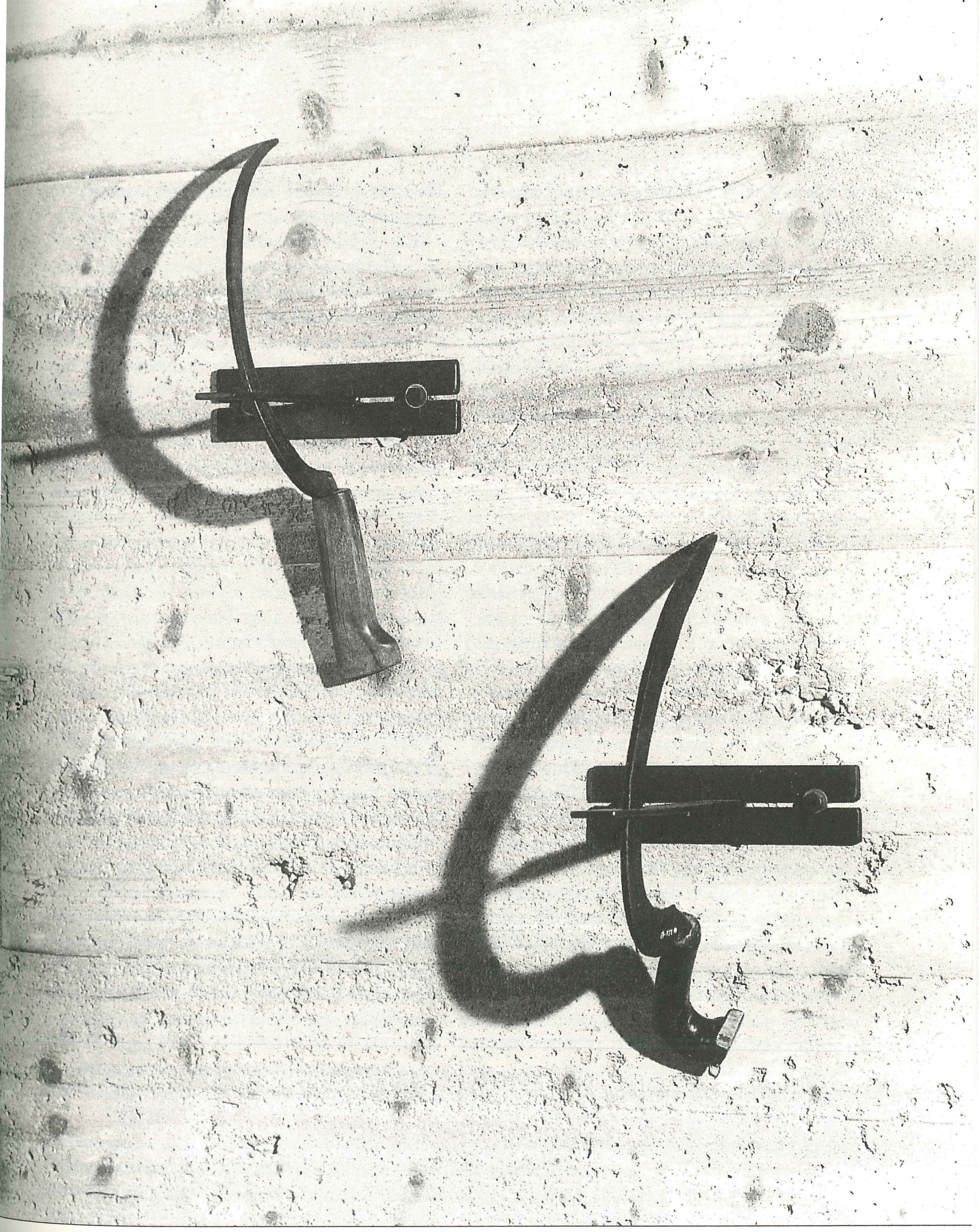


90 finnes ikke mer. Fortid eksisterer bare som hukommelse. Fortidige kan de gamle gjenstandene bare bli $\mathrm{i}$ vår bevissthet, $\mathrm{i}$ den grad vi makter å tenke dem inn i historiske sammenhenger, og forestille oss hva de en gang kan ha vært. ${ }^{49}$

Tingene narrer oss til å tro at de er stykker av fortid som har vedvart, at de kommer til oss fra den andre siden av dette lange tidsforløpet de bærer merkene efter, med sin egen forgangne nåtid intakt - klar til gjenbruk. Slik Birger Nesholen: «Når gjenstanden eksisterer her og nå, eksisterer også deler av fortiden her og nå.» ${ }^{50}$

Dette er tingenes andre felle: De innbyr til å «oppleve fortiden».

Spor efter tidens tann forringer ikke tingenes evne til å illudere tidens opphevelse. Snarere tvertimot. Et vikingesverd eller en kirkeruin som er så hentæret at informasjonsverdien for den uinnvidde er omtrent lik null, oppskattes allikevel høyt for all den tid de har gjennomlevet, tydelig nedfelt $\mathrm{i}$ forfallstegnene. Det rommer den opplevelseskvalitet som Walter Benjamin kalte aura $^{51}$; i faglitteraturen gjerne omtalt som aldersverdi. "Forvitring, slitasje og gammelmodig form gir følelsen av kontakt med tider bakenfor ens egen erfaring», skriver Dag Myklebust. ${ }^{52}$ På samme måte som rynker og furer tyder på at mennesker er gamle og dermed har en fortid. «Som om tingene kunne huske!», sukker Anders Johansen. "Dreier det seg ikke direkte om en forveksling av alder og fortidighet i slike opplevelser, da dreier det seg $\mathrm{i}$ alle fall om besjeling. ${ }^{53}$ Derfor gjør da heller ikke nytilvirkede kopier nytten på et museum: De fremstår riktignok som komplette, brukelige og nye, slik originalgjenstandene vitterlig må ha gjort i sin tid, men det kompenserer ikke for fraværet av den nimbus som følger av delaktighet $\mathrm{i}$ et langt tidsforløp.

Iflg. Anders Johansen skulle det faktum at folk får en følelse av kontakt med fortiden uten virkelig å ha det, med all tydelighet vise at enhver slik kontaktfølelse er illusorisk, og at alle forsøk på å dyrke den frem, med autentiske eller bare tilsynelatende gamle ting, er lureri. Hva publikum kan narres til å svelge som fortid er legio, og det blir et moralsk spørsmål i hvilken grad man skal tydeliggjøre hva som er autentisk og hva som er senere tilføyelser. Men lureriet oppstår alt før tydeliggjørelsen, nemlig i det øyeblikk man gir publikum troen på at tingene kan gi kontakt med fortiden, uaktet hvilket gjenstandsmateriale man benytter for å «formidle» denne kontakten.

Invitasjonene til fortidsopplevelse befordres av kontinuiteter i rommet, ikke i tiden. Fortiden kommer aldri tilbake, men i det fysiske rom «kan tingene bli værende i samme posisjon hele tiden, ${ }^{54}$ her - og bare her - kan våre koordinater være sammenfallende med tidligere slekters. Når vi tror oss å oppleve historiens nærvær, beror det på en forveksling av dimensjonene tid og rom.

Mens «ortodoksien» holder fast ved gjenstandens informasjons-, visualiseringsog formidlingspotensiale, blir Anders Johansen ved med å understreke at gjenstanden $i$ seg selv er meningsløs. Mening oppstår av synsvinkelen vi anlegger på den og sammenhengene vi innskriver den i. Han finner det derfor absurd at en hvilken som helst gjenstand som på en eller annen måte har tilhørt eller vedrørt mennesker som bodde her i landet, skal tilskrives «vår felles fortid»: "Vi», det nålevende norske folk, er ikke noe kollektivt individ med 
«minner» fra tidligere liv, ei heller en "slekt» med en viss karakter som videreføres i form av «kulturarv» fra «fedrene» slik at denne fortiden kan være "vår». Vi har ingen grunn til å ta våre forgjengeres dyder til inntekt for vår egen fortreffelighet, ei heller til å skamme oss over deres misgjerninger: Fortiden er tilbakelagt, og den er hverken vår skyld eller vår fortjeneste. Den tilhører kort sagt ikke oss. Troen på tilhørighet i historien beror dels på en overbetoning og mystifisering av kontinuiteter i slektenes gang med støtte i tilsynelatende vedvarenhet innenfor gjenstandskulturen, dels på den nevnte forveksling av dimensjonene tid og rom. Johansen siterer antropologen Fredrik Barth, som påstår at forskjellen mellom nordmenn og indere flest er mindre enn forskjellen mellom nordmenn av idag og de som levde i 1814. Identitet er ikke vedvarende, hverken innenfor den enkeltes liv eller for et folkeferds vedkommende. Den oppløses, som regel evolusjonært, sjeldnere i store sprang. Før eller siden havner man i helt fremmed land. Dette til tross insisterer vi på å bevege oss bakover i tiden på jakt efter identitet og samhørighet, ikke sideveis. "Om vi det gjorde," skriver Johansen, «ville vi kanhende få inntrykk av at vi er hva vi velger å være eller slumper til å bli» ${ }^{55}$, ikke - som idag tro oss å være historiens barn, det uomgjengelige avkom av historiens nødvendighet.

Johansen bestrider ikke at museene befordrer en følelse av identitet. Det lar seg ikke nekte at f.eks folkemuseene og stavkirkene har bidratt vesentlig til etableringen av en nasjonal identitetsfølelse her i landet. Heller ikke bestrider han behovet for holdepunkter i en omskiftelig og tur- bulent tilværelse: Han betoner at vi i det urbane mangfold og under inntrykk av medieflommen stilles overfor mange og tildels sterkt motstridende virkeligheter, og at sentrifugalkraften i dette mangfoldet gjør det vanskelig å fastholde en følelse av identitet. Derfor er det ikke uforståelig at man søker i fortiden. Fortiden synes trygg. Den er avsluttet, den har funnet sin form én gang for alle. Den fremstår ikke som åpen, uoversiktlig, uforutsigbar og angstskapende som den vitale aksen nåtid-fremtid. Slik museene fremstiller fortiden, ved hjelp av enkle modeller som bekrefter forhåndsdommen over fortiden som sikker grunn, og ved å fremholde den materielle delen av kulturen, den som avhjelper følelsen av identifikasjon, er det bare rimelig at man fristes til å slå rot i den.

Det er dermed godt tenkelig at museenes fortidspresentasjon tilfredsstiller et faktisk behov for trygghet. Men det er en falsk trygghet, og denne rent symbolske vending bakover er bortimot vårt eneste svar på det ytterst problematiske stormløp forover: Historie stilles opp som motvekt til samtidshistoriske forandringer; som motgift til historie. Samtidig innebærer museenes dobbelte ambisjon om dels å bidra til identitetsbygging og tradisjonsbevissthet, dels å forvalte historisk kunnskap og perspektiv, en umulighet: Stoff til identitetsbygging kan bare hentes ut av historien $i$ den utstrekning historiserende perspektiver blir satt ut av kraft. Det dreier seg om prosesser med vidt forskjellig utkomme.

En historiserende kunnskapsformidling innebærer, i motsetning til den hvis siktemål er identitet, erkjennelsen av at alt jeg er og alt jeg står for er betinget av spesielle og forbigående omstendigheter: "Jeg kan 
92 komme til å bli klar over at hva vi forstår med galskap er en ny oppfinnelse, på samme måte som barndommen, og dødens realitet, og morskjærligheten, kvinneligheten, pinlighets- og avskyreaksjonene våre så mye av dette vi tar for å være naturlig tid, rom, historie, individuell og nasjonal identitet, osv. Da kan jeg fort komme til at alt er historisk, at jeg er et vesen av ingen ting og hva det måtte være, og noe bestemt bare av tilfeldig omstendighet. I lys av det historiske perspektivet blir jeg nødt til å se meg selv utenfra, og da er jeg mindre enn noen gang ett med meg selv: $\mathrm{Da}$ stiller jeg meg snarere undrende til meg og mitt. ${ }^{56}$

Hvordan kan så museene bidra til å fremme en slik historiebevissthet? Johansen fremhever den presentasjonsmodellen som nærmer seg renessansens raritetskabinett, der alskens fragmenter av liv fra alle slags steder og situasjoner hoper seg opp, som ingredienser $\mathrm{i}$ et surrealistisk maleri, $\mathrm{i}$ en kompleks og mangetydig montasje. Her, i den usystematiske, utekstede tidscollage, antar tingene mening på ny: som de sammenhenger den enkelte betrakter makter å opprette $\mathrm{i}$ alt dette usammenhengende. Her finnes uendelige muligheter til betydningsdannelse, snarere enn enkle budskap om historie, tradisjon og identitet. Jo mer overraskende sammenstillingene er, desto rikere er muligheten for at betydninger skal oppstå av spenningsforholdet mellom gjenstandene.

I større eller mindre grad manifesterer dette collage-preget seg ved ethvert museum - moderne pedagogikk toner det bare ned. Johansens vareopptelling fra bysamlingen i Historisk museum i Bergen avdekker bl.a. følgende: «Ole Bulls violin, taktstokk, notestativ, laurbærkrans og champagnebeger. Gullsmed Olsens fruktoppsats til Verdensutstillingen i 1902. En glassbolle, skjenket stiftamtmann Cicignon av byens borgere, som takk for innsatsen i Strilekrigen. En klavikord, som kjøpmann Tyrholms hustru Alette, født Rode, skal ha lært å spille på av Claus Fasting, påmalt Sfinx.[...] $\|^{57}$

Dette identifiserer Johansen som et utpreget, om enn utilsiktet moderne trekk ved museet: samlingenes grunnleggende surrealistiske preg blir et bilde på at den orden vi ønsker å innskrive fortiden $\mathrm{i}$, ikke eksisterer. Når tingene står opp mot hverandre gis tanken mulighet til selv à foreta krysskoblinger, etablere betydninger stikk i strid med alle vedtatte sannheter. Slik reetableres kanhende fortiden som mangetydig, uavklart, sitrende av muligheter. Tryggheten forsvinner, men også den ledsagende følelsen av å være fanget i fortidens vold. Øyeblikket frisettes.

Denne observasjon låner Johansen fra Billy Ehn, som hevder at når tingene står slik mot hverandre, kaster de av seg de tvangstrøyer som fastholder dem i en stor og endelig fastlagt beretning. Dermed anskueliggjør utstillingen den innsikt at en ting ikke er noe annet enn kontekstene hvori den innskrives, og at det samme gjelder for en person, en situasjon, en nasjon. Den museale måten å betrakte verden på - det Ehn kaller museendet - handler om å se noe annet enn det opprinnelige.

Tingen isoleres og forvandles, som når man sier et ord så mange ganger at det taper sin mening: Man hører bare lyden. Så skjer også med gjenstanden i monteren. Den overskrider sin funksjon og betydning og blir til et tegn. Med tegn kan man leke og søke seg fram i nye kombinasjoner, uten å være 
bundet av foreliggende kontekst... Man blir seg selv bevisst som betrakter og betydningskonstruktør: I tanken kan man gjøre hva som helst med omverdenen, gi tingene nye navn, se uventede kombinasjoner, assosiere fritt og leke gal. [...] respekten minker for etablerte betydninger, siste ord er ikke sagt. ${ }^{58}$

For Johansen er hensikten med historieforståelse åpenbar: $\AA$ hjelpe oss av med historiens byrde, slik at vi kan rette vår beredskap mot fremtiden. Kun derved kan vi få bremselengde, muligheter til å omstille oss i tide og være med å styre utviklingen. "Får vi det ikke,» sier han, "kan vi bli ofre for "framtidssjokk»: Vi kan bli sittende desorientert og akterutseilt, slik de fleste gamle gjør det allerede, og ikke lenger kunne forstå eller sympatisere med vår egen samtid.."

Johansen ender sitt felttog med å sitere Benedetto Croce: «...Historieforståelsen forvandler det fortidige til sitt eget materiale og sitt eget objekt, og frigjør oss fra historien" ${ }^{60} \mathrm{Og}$ siden historieforståelsen i det vesentlige kun frembæres av ordene, blir de gamle tingene kun en del av vår fremtidsberedskap såfremt de tjener «som kilder og som illustrasjoner, for kald, historisk kunnskap». ${ }^{61}$

\section{FEHN OG RARITETSKABINETTET}

Raritetskabinettet og det surrealistiske museum har for Johansen det til felles at de begge inviterer betrakteren til å se nye sammenhenger $i$ alt det forvirrende. «Fasithistorien» suspenderes, og man blir selv betydningsentreprenør. Hvis man først ser at tingen tar farve av de kontekster den innskrives i, er ikke veien lang til erkjennelsen av at dette ikke bare gjelder tingene, men også oss selv. Inviterer Fehns museum til den samme oppdagelse? Mitt svar er ja, og jeg skal søke å begrunne det i det følgende.

Formidling av fortid gjennom gjenstander hviler på en vesentlig forutsetning, nemlig at det finnes konstanter i menneskets forhold til tingene som setter oss i stand til å oppfatte noe av det samme som den historiske aktør ved synet av dem. Hvis gjenstandene skal kunne fortelle noe vesentlig om sin opphavstids livsverden, er det en forutsetning at vi som "mottagere» har noe grunnleggende tilfelles med «avsenderne». Isåfall vil vi ved å befatte oss med fortidens levninger oppleve noe av det samme som deres brukere. Gjenstandene vil da fungere som døråpnere til historiens rom.

Etnologen Inger Lise Christie gjør seg til talsmann for et slikt syn på gjenstandsformidling når hun hevder at ingen andre kildetyper kan erstatte gjenstanden. «Hvilken skriftlig kilde kunne bibringe det samme som en eneste bevart stavkirke? [...] Kan noen annen kilde formidle hva en eneste nedslitt skyttel kan si?», spør hun. ${ }^{62}$ For henne er gjenstanden en primærkilde i kraft av sitt materielle nærvær, sine taktile og visuelle egenskaper. "Gjenstanden kan ikke lyve», hevder hun. Finn Jor følger samme forlegg når han slår fast at «det gir en helt annen innsikt å holde en steinøks i hånden enn å lese om den i en bok. Og man skjønner mer både av båter og livsforhold når man ser en fembøring enn når man hører foredrag om den. Det er denne ordløse bevissthet, denne overlevering av den tingliggjorte erfaring, som er museenes styrke. Her lever mange tider samtidig, vi kan gå ut og inn $\mathrm{i}$ historien, for menneskene er nok i det store og det hele uforandret. ${ }^{63}$ Likeledes 
94 Christie: «Tidene forandrer seg, mennesket forblir det samme. Dette innebærer at rent fundamentalt er mennesket i tid og rom opptatt av det samme: sitt forhold til samfunn, fysiske omgivelser og gudene/ maktene. Dermed vil det symbolske innhold i tid og rom bestå av et relativt begrenset repertoir, mens de gjenstander som representerer dette innhold vil fremstå i utallige utforminger. ${ }^{64}$

Utifra enkeltstående utsagn virker det ikke urimelig å ta Fehn til inntekt for et tilsvarende syn. Som tidligere referert gir han uttrykk for at gjenstandene gjennom en optimal eksponering skal «fortelle historien ${ }^{65}$ Dessuten beriktiger han $i$ et intervju ${ }^{66}$ at han deler den oppfatning som Aldo van Eyck uttalte under CIAM-kongressen i Otterloo i 1959: At mennesket overalt og alltid essensielt er det samme. ${ }^{67}$ På dette grunnlag kunne man være fristet til å se en forbindelse mellom Fehns arbeid og den «ortodokse» gjenstandsformidling.

Dette er dog høyst problematisk. Som vi har sett, tar han sterkt avstand fra historiske rekonstruksjoner. I dette er det nødt til å ligge en avskrivning av mulighetsbetingelsene - herunder også den ovennevnte for slike rekonstruksjoner. Om middelalderutstillingen på Høvikodden i 1972 sier han da også: «[...] du har ikke det publikummet, du har ikke den kirken, du har ikke den muren, du har ikke den fortiden.» I dette ligger det vel nettopp en innrømmelse av at menneskene har forandret seg så meget at det ikke kan oppstå samsvar mellom det "avsender» og "mottager» oppfatter i møtet med samme gjenstand. $\mathrm{Og}$ når han forsvarer sin liggende Kristusfigur, hevder han: «Man har jo allikevel løsrevet figuren fra tid og rom. Det gir frihet til ny vurdering og nye opplevelser. ${ }^{68}$

Fehn går i det hele tatt sterkt i rette med tendensen til å levendegjøre den materielle del av en kultur i den tro at vi dermed forstår den livsverden som den korresponderer med:

Når man leser Borges' oversettelse av vikingenenes vokabular: øynene er kloder i universet, helt fantastiske beskrivelser, en poetisk styrke som vi er langt unna; vi har ikke begrep om det engang. Det [vi har] er jo så fattig i forhold til det de hadde og dro nedover med, så der er jeg så redd for disse virkeliggjørelsene av en virkelighet i forhold til vår; det er den som blir så absurd, egentlig. På grunn av vår behagelige åndsfattigdom, på mange måter. Så hvis man ser alt ut fra det materielle, brynjer og slag og sånt noe: De dro nedover med hele denne poetiske verden og denne pluralistiske gudeverden inn i høymiddelalderen med sine båter. Klart det ble kollisjoner og voldelighet, men det har en høyere dimensjon enn jeg synes det fremstilles som. Og hva med denne voldsomme returen, når de kom tilbake. Pga disse refleksjonene er jeg veldig redd for å leke synliggjørelsen av disse eksistensene. [...] Da kommer man over i en nedvurdering av disse epokene med sine voldsomme kvaliteter. ${ }^{69}$

I forbindelse med sitt gjenstandsløse bremuseum uttaler Fehn: "Et tradisjonelt museum arbeider med å synliggjøre de forlatte gjenstander. I dag føler vi nødvendigheten av at museene skal synliggjøre det usynlige. $\rangle^{70}$ Med andre ord må det være noe gjenstandene alene ikke viderebringer. Deres ordløse formidling er ikke «komplett».

Det kan derfor se ut som om Fehn er i motstrid med seg selv: På den ene siden er det hans ambisjon å eksponere gjenstandene på en slik måte at de selv blir istand 
til å "fortelle historien», mens han motsatt hevder at gjenstandene i seg selv er utilstrekkelige som formidlere. Nøkkelen til en harmonisering av disse hevdelsene må være å finne i Fehns bruk av begrepet «historien». Under avsnittet om Fehns utstillingsmetodikk har jeg søkt å begrunne at «historien» for Fehn er det «noe» som blir til i betrakterens hode ved synet av gjenstanden, med utgangspunkt i vedkommendes forutsetninger - med andre ord ingen korrekt oppfatning av den fortidige virkelighet slik den engang fortonte seg for den historiske aktør. Under samme synsvinkel tror jeg man må oppfatte bruken av ordet «fortiden» i utsagnet: "Kun ved å manifestere nuet får man fortiden $\mathrm{i}$ tale.» Her er det antagelig fortidens levninger Fehn snakker om, ikke fortiden selv. Levningene kan, hvis de utstilles på en stimulerende måte, fungere som råstoff til fantasien.

Fehns intensjon ser altså ut til å harmonere med den hensikt Johansen mener raritetskabinettet oppfyller, nemlig å frisette fantasien til selv å operere meningsdannende. Men reflekteres dette i utstillingene? Ved første øyekast kan det synes som om Fehn befinner seg i nærheten av det tradisjonelle museet slik Johansen fremstiller det. Gjenstandene står alene, uten ledsagende tekster som klargjør deres historiske omstendigheter. De er ordnet tematisk i avsnitt, av og til også typologisk innenfor det enkelte avsnitt, med andre ord synes de innskrevet $\mathrm{i}$ en orden som ifølge Johansen ikke eksisterer. Her finnes også tilløp til substitusjon. Men ved nærmere eftersyn legger man merke til mangt som ikke passer inn i dette bildet, og man innser snart at museet også i praksis nærmer seg det «surrealistiske» museet
Johansen beskriver. I det følgende skal jeg 95 nærmere begrunne hva som tilsier denne oppfatning.

Manfredo Tafuri opererer med to måter å forholde seg til et fragment: nostalgisk/ begråtende, eller som en invitasjon til fabulering. Tafuri finner at Scarpa velger den siste: Han synes å skape en atmosfære rundt gjenstandene som løsriver dem fra tidens og rommets dimensjoner; lar dem folde seg ut i en annen virkelighet hvor de inviterer til undring og meddiktning. Arkitekten innfører et brudd, som angivelig tillater betrakteren å forandre modus i møtet med verket.

Det samme mener jeg kan gjøres gjeldende for Fehns monteringer. Kontrastvirkninger i materialer og formsprog skaper i mange tilfeller sterke spenninger mellom den gamle gjenstand og den nye monter, som virker befordrende på fabuleringsevnen. Av og til - som med «djevelens finger» - oppstår i denne betrakter en følelse av forvirring eller uvirkelighet. I slike tilfeller kommer monteren til å fungere som et tankens springbrett.

Bare i liten grad er assosiasjonene "styrt" av skriftlig eller visuell informasjon; de viktigste føringer ligger i betrakterens observasjonsevne, kunnskaper, erindringer, fabuleringsevne og refleksjonsnivå. En gammel bonde fra distriktet vil knytte personlige minner til gjenstandene og veve dem sammen med en fortid som fortsatt eksisterer i hans hukommelse. Et barn fra en storby - for hvem gamle jordbruksredskaper med anakronistiske lokalbetegnelser («førard», «jernskoroko», «åfløy») knapt forteller noe som helst - vil derimot stå fritt til å la sin fantasi avstedkomme de mest fantastiske beretninger. 
96 I noen tilfeller antydes riktignok gjenstandens funksjon temmelig klart: Hedmarksarden er montert slik at det antagelig helt uten forkunnskaper er mulig å gjette seg til at dette må være et redskap til å vende jorden med $^{71}$ Andre monteringer underslår helt den handlingsimpuls som ligger nedfelt i gjenstandens form - typeeksemplet her er monteringen av de to opprettstående sledene, som fokuserer på formale snarere enn funksjonelle kvaliteter.

Surrealistene ville stille spørsmålet: «Hva er en ting?», påny og påny. Marcel Duchamp svarte ved i 1914 å utstille et urinal og et flasketørrestativ. (ill. 31) Man kalte den handling å ta en ting ut av sin vante sammenheng og utstille den på et museum for "dépaysé»" - gjenstanden eksileres, forrykkes og blir en forrykt eller vill ting. Noe av det samme er det som skjer i Fehns montering av sledene: Han desymboliserer dem, slik at de kan inngå i nye, overraskende sammenhenger. ${ }^{73}$ Ved a utstille gjenstandene på andre måter enn de tradisjonelle, understrekes deres karakter av tegn, hvis tolkning beror på den kontekst de innskrives i og de kunnskaper vi har om dem. Fehn hevder riktignok at når sledene stilles opprett, er det for å aksentuere formen, men han vet at han dermed underkjenner deres didaktiske potensiale og viser oss deres tegnkarakter. Kanskje er sledene og den glidende utsikten fra broen ${ }^{74}$ de mest iøynefallende eksemplene på at Fehn søker å si noe om relasjonen mellom tegn og mening, men langtfra de eneste. F.eks. fremstår skyruene nesten som arabiske skrifttegn mot den grå bakveggen.

En utbredt innvending mot Fehns utstillinger målbæres av Gunnar Danbolt.
Han skriver følgende om Fehns middelalderutstilling i 1972, som han sammenligner med en tilsvarende, "omtrent samtidig» utstilling på Oldsaksamlingen:

Her var det tingen selv som sto i sentrum - middelalderkrusifiksene hang ikke på veggen, de lå på glassplater, og var estetiske objekter her og nå, helt på linje med samtidig kunst. Det var usedvanlig vakkert, men fortiden var alldeles uteglemt. ${ }^{75}$

Med andre ord: For Danbolt kommer «det estetiske objekt" i veien for "det historiske fragment». Annetsteds innrømmer imidlertid Danbolt at den mekanisme som kommer inn og ødelegger museenes utstillinger - og her taler han om utstillinger generelt - er at gjenstandene de opererer med "har fått ny betydning med tiden og er blitt forvandlet til verdifulle antikviteter». ${ }^{76}$ Han kritiserer altså Fehn for noe han vedgår er nødt til å inntreffe uansett. Herunder kommer han til å overse at mens mange utstillinger søker å underkjenne eller kamuflere gjenstandens nåtidighet ved å rekonstruere dens brukssammenheng, noe som sjelden lykkes fordi premissene mangler, tar Fehn skrittet fullt ut og innrømmer åpent at gjenstanden har en annen status idag; at den har gjenoppstått som noe annet enn den engang var. Møkkagreipet, en av de minst estimerte gjenstander dens brukere vel kunne tenke seg, fremstår i Fehns montering som et estetisk objekt på linje med ziratflaskene. Dermed blir den i høyeste grad nåtidig. Men samtidig gjør understrekningen av gjenstandens diametrale anderledeshet den til et tegn man føler seg fri til å leke med i tankene. Fehn viser oss derfor gjenstanden både som nåtidig eksistens med de kvaliteter det innebærer, og som et mystisk tegn 
fra en fortid som ikke lenger eksisterer. Ikke på samme tid, men avvekslende, på samme måte som den lille tegningen Ernst H. Gombrich viser i Art and Illusion alternerer mellom å forestille en and og en kanin. ${ }^{77}$

Jeg oppfatter det som om Fehn med sin insistente betoning av gjenstandens tegnkarakter begir seg inn på en demokratisk utstillingsstrategi: Utstillingen inviterer til å erkjenne at din historie kan være like god som min; at enhver beretning om fortiden er grunnleggende hypotetisk og feilbarlig.

Fortiden [...] er en levende struktur som alltid fortoner seg forskjellig, i en dynamisk prosess. Det å finne elementer $\mathrm{i}$ fortiden blir da en skapende handling. ${ }^{78}$

Denne observasjon er helt i pakt med nyere vitenskapsfilosofi. Idéhistorikeren Per Strømholm skriver:

Innenfor klassisk kunnskapsteori var drømmen om en absolutt, objektiv og overhistorisk kunnskap det viktigste motivet. Det er idag liten grunn til å betegne dette idealet som annet enn en kollektiv, intellektuell psykose: Moderne vitenskapsteori nærer en allmenn skepsis til teoretisk kunnskaps sikkerhet og til all rekonstruksjonsretorikk relativt til fortida. ${ }^{79}$

Vi har efterhvert blitt klar over at kunnskap om fortiden kan aldri bli noe annet enn kunnskap for oss, her og nå. Vi definerer fortiden $\mathrm{i}$ våre termer, utifra våre interesser og $\mathrm{i}$ en vesentlig forstand derfor på våre premisser. Disse størrelsene gjennomgår kontinuerlige forandringer, samtidig som tilfanget av det materiale vi bygger våre teorier på, jevnt over vil utø- kes. Kunnskapen er derfor ikke som en gotisk katedral; den er en prosess og ikke noe produkt. Den er selv historisk, dvs. farvet av den tid den kom til i.

For Fehn er dette en realitet, og hans motvilje mot "fasithistorien»; mot å finne seg selv og sin fantasi fastholdt $i$ en endegyldig, tingliggjort beretning, står tydelig å lese i hans utstillinger. I så måte har han adskillig tilfelles med raritetskabinettet; ikke så meget $\mathrm{i}$ intensjon, men $\mathrm{i}$ effekt. Begge inviterer de betrakteren inn i et rom der man er sin egen meningsskaper, uforpliktet av etablerte betydningssammenhenger

\section{SUMMARY}

Sverre Fehn and his theory of exhibitions

In the 17th century a largebarn was erected on the ruins of a medieval bishop's residence at Hamar in Norway. Today it has been transformed into a historical museum, Storhamarlåven. The exhibition of historical objects has been designed by the famous architect Sverre Fehn. In this paper, which is a chapter in a more extensive study of Fehn, the author analyses the exhibition against the background of Fehn's own writings and statements made in press interviews. The author finds that Fehn in his adherence to modernism, is akin to Elias Cannetti who has characterized 'history' as an old vampire sucking the blood out of young people's brains and who argues that people who do not make their way out of history are irretrievably lost. How can Fehn combine the modernistic rejection of everything with a taste for history and nationalism with the museological responsibility to further identity and factual historical information? Both aims to be achieved through the medium of material objects. 
NOTER

1. Fehn 1970: 52-62

2. Fehn 1994

3. «Vitenskapen har berøvet menneskene troen på himlenes rike. Religion idag er å forhindre døden. Heller ikke gjenstandene får lov å dø, de skal konserveres. Ruiner skal ikke forringes, men beholde sin nåværende tilstand til verdens ende. (...) Ingenting må falle fra hverandre eller forsvinne. (Fehn 1992C: 48)

4. Fehn 1994

5. Fehn 1985B: 10

6. Fjeld 1982: $93 \mathrm{ff}$

7. ibid.: 94

8. loc.cit.

9. loc.cit.

10. loc.cit.

11. ibid.: 96

12. Fehn 1985A: 353

13. Fjeld 1982: 96

14. Pedersen 1989: 29

15. Fehn 1975A: 58

16. "The building as a 'drawer' only hinders the viewer's ability to sense the magic displayed.» (Fjeld 1982: 96)

17. Fjeld 1982: 96

18. Fjeld 1982: 96

19. Fehn i intervju med Pedersen (Pedersen 1989: 28)

20. Fjeld 1982: 96

21. Fehn 1994

22. Fehn 1994

23. Setningen er lånt hos Brockmann 1986: 118. Kfr også flg utsagn, hentet fra Mathilde Petris intervju med Fehn: «Og historien er et digt om en familie, en by, en akrobat, en fange, en dødssyg, en aktør, en pianist...» (Fehn 1990B). I The thought of construction sier Fehn ogsa flg, om folkemuseumsfløyen: «This is a market place for various types of exhibition and display, a reflection of different personalities and ambitions. [...]
The image is of people striving together to overcome privation and to fulfill their hopes and dreams; their tools, letters, inscriptions and drawings symbolize a history.» (Fjeld 1982: 130)

24. Fehn i intervju med Pedersen (Pedersen 1989: 29)

25. Fehn i intervju med Pedersen (Pedersen 1989: 27)

26. Fehn 1988: 16

27. «Keiserens Hær», utstilling av skulpturer fra keiser Qin Shihuangs grav. Henie-Onstad Kunstsenter 1985.

28. «...det er sjelden man er så heldig at de gjenstandene som du stiller ut i museet er laget i det regionale lyset som de er i. Det er fenomenalt. Og i tillegg har du det såkalte tragediens lys, altså ruinens fall, og gjennom disse åpningene faller lyset inn. Så der har du en historisk lyssetting som er uvurderlig. Det gir objektene et mysteriøst, spennende lys.» (Fehn 1994)

29. "Arealene er gitt, og du skal sette i scene en historie av gjenstander og arkitektur, lys og bevegelser som spenner over en periode på 1000 år.» (Fehn 1992A: 86)

30. Petri 1990: 34

31. Man har flere steder sett seg nødt til å eftersikre gjenstandene med små, usynlige nagler.

32. Marinetti 1965, 435

33. Partiet gjengitt på norsk hos Johansen 1990: 44

34. Beyer 1973: 109

35. En annen av fascismens litterære medløpere var imidlertid Gabriele d'Annunzio, som var en utpreget klassisist. Da han oppflammet Italia til å gå med i første verdenskrig, hentet han sine argumenter fra landets storhetstid. Vi ser altså at en bevegelse hvis tankegods i stor grad ble foregrepet av futurismen, hadde premissleverandører også innenfor den stikk motsatte leir. Dette illustrerer fascismens ambivalens, men forteller antagelig også en hel del om tidens ideologiske forvirring. At man bekjente seg til en bevegelse innebar ikke nødvendigvis at man aksepterte hele 
dens ideologi.

36. Som motvekt kan man $\mathrm{f}$ eks trekke frem Le Corbusier, en av grunnpillarene i den modernistiske arkitekturen, som hevdet at han bare hadde én læremester, nemlig fortiden, og at han bare kjente én displin, nemlig fortidsstudiene.

37. "Passatistisk» var et skjellsord som ble brukt om alt som hadde med fortiden å gjøre; lansert av Marinetti.

38. Murphy 1990, 9

39. "Museum Europa. En udstilling om det europæiske museum fra renæssancen til vor tid»; Nationalmuseet 19. juni-24. oktober 1993. Katalog med samme tittel utgitt til utstillingen.

40. Nielsen 1993, 7

41. Danbolt 1991: 71f

42. Danbolt 1991: 72

43. Lie Christensen 1994: 16

44. Jfr. ICOM-statuttene

45. Jfr. bl.a. Stortingsmelding nr. 60, som kom ut i 1985.

46. Med dette legger han for dagen et kultursyn som - motsatt en materialistisk orientert anskuelse - betoner den immaterielle kulturens overordnede betydning.

47. Ehn 1986: 55

48. Anderson 1984

49. Johansen 1990, 12

50. Nesholen 1991, 19

51. Benjamin 1991: 37ff

52. Myklebust 1981

53. Johansen 1990: 13

54. ibid.: 15

55. Johansen 1992: 28

56. Johansen 1990: 18

57. Johansen 1992: 30

58. Ehn 1986: 71-72. Gjengitt på norsk hos Johansen 1991: 57

59. Johansen 1990: 26

60. Croce 1941: 59. Gjengitt på norsk hos Johansen 1991: 57

61. Johansen 1990: 27
62. Christie [årstall ukjent]: $188 \mathrm{ff}$.

63. Jor 1985: 12

64. Christie: 195

65. "Den andre måten er å ta objektet som det er og presentere det på den beste måten, slik at gjenstandenes form forteller historien.

Oppbyggingen av gjenstandene forteller nakent sin historie.» Fehn i intervju med Pedersen.

(Pedersen 1989: 29)

66. Fehn 1994

67. Gjengitt hos Frampton 1992: 276. Sitatet lyder: «Man is always and essentially the same. He has the same mental equipment though he uses it differently according to his cultural or social background, according to the particular life pattern of which he happens to be a part.»

68. Fehn 1975A: 58

69. Fehn 1993

70. Fehn 1992B: 105

71. Bjarne Rogan hevder riktignok: «En person fra et primitivt hakkejordbruk ville aldri ha forstått hva en plog kunne brukes til, dersom han plutselig var blitt stilt over et eksemplar av dette "klassiske» objektet.» (Rogan 1991: 44) Når jeg tror dette ikke har gyldighet her, er det fordi monteringen gir en tilleggsinformasjon som ikke ligger i gjenstanden selv. Derfor mener jeg også dette er en «svakt» litterær utstillingsform.

72. Jfr. Nielsen 1993: 40

73. Jfr. Tafuri om Scarpa.

74. Jfr. kap. 2.2.3

75. Danbolt 1990: 21

76. Danbolt 1991: 78

77. Gombrich 1992: 4

78. Fehn 1992: 48

79. Strømholm 1990 


\section{LITTERATUR}

Anderson, J. 1984: Time Machines: The World of Living History. Tenessee

Benjamin, W. 1991 (1936): Kunstverket i reproduksjonsalderen. Norsk overs. ved Torodd Karlsten (1975), 2. utg. Oslo

Beyer, E. et.al. (red.) 1973: Verdens litteraturhistorie bd. 10: Århundreskiftet

Brochmann , J. 1986: Det enkle som er vanskelig å gjøre. [anmeldelse av boken The Thought of Construction] Byggekunsts. 118-119

Christie, I.L. u.å.: Gjenstander som grunnlag for forskning og formidling. By og Bygd, bd. 32

Danbolt, G. 1990: Mellom ting og tegn. I: Museene mot à 2000 - utfordringer og muligheter [rapport fra NKKMs fagseminar 1990]. Oslo, s. 20-23

Danbolt, G. 1991: ^̊ samle på vind og ingenting. I: Gjenstanden - verdi og virkning [rapport fra NKKMs fagseminar 1991]. Oslo, s. 69-79

Fehn, S. 1970: A propos museer. Museumsnytt 1970: 52-63

Fehn, S. 1975: Middelalderutstilling på Høvikodden. Byggekunst 1975: 58-60

Fehn, S. 1982: Fragmenter av et museum og to utstillinger. Byggekunst 1982: 165-172

Fehn, S. 1985 A: Kinesiske soldater på Høvikodden. Byggekunst 1985: 348-353

Fehn, S. 1985 B: AA Files 1985 no. 9

Fehn, S. 1988: Sjelens anatomi. I: Lunde, I.M. og S. Wiik (red.): Jan Groth. Tegn. Oslo

Fehn, S. 1990 [Fehn intervjuet av M. Petri]. Scala 1990: no. 4

Fehn, S. 1992 A: Hedmarksmuseet på Domkirkeodden, Hamar. Byggekunst 1992: 8699

Fehn, S. 1992 B: Norsk bremuseum i Fjærland, Balestrand. Byggekunst 1992: 104-106

Fehn, S. 1992 C: En arkitektonisk autobiografi [Fehn intervjuet av M.-R. Norri]. I: Norri, M.R. og Kärkkäinen, P. (red.): Den rette linjes poesi, 45-51
Fjeld, P.O. 1982: Sverre Fehn. The Thought of Construction. New York

Frampton, K. 1992: Forord til Fjeld, P.O.: Sverre Fehn. The Thought of Construction, 10-17

Gombrich, E.H. 1977: Art and Illusion. London (5. oppl.)

Johansen, A. 1990: Museets modernitet - del I. Samtiden 1990: 40-49

Johansen, A. 1992: Museets modernitet - del II. Samtiden 1991: 56-65

Jor, F. 1985: Museenes problem: det begivenhetsorienterte menneske. Museumsnytt 1985 (3-4): 12

Marinetti, F.T. 1965: The Futurist Manifesto. I: Ellman, R. og C. Feidelson (red.): The Modern Tradition. New York, s. 433-435

Murphy, R. 1990: Carlo Scarpa and Castelvecchio. London 1990

Myklebust, D. 1981: Verditenkning - en arbeidsmåte i bygningsvern. I: Fortidsminneforeningens årbok 1981

Nielsen, A.V. (red.) 1993: Museum Europa [utst.kat.]. København

Pedersen, R. 1989: Storhamarlåven - et bygningshistorisk konglomerat. Museumsnytt 1989: 27-29

Petri, M. 1990: Vital Confrontations in the Architecture of Sverre Fehn. [upubl. oppg. fra AA School of Architecture, London 1990]

Rogan, B. 1991: Har gjenstanden noen kildeverdi i et nåtidssamfunn? I: Gjenstanden - verdi og virkning [rapport fra NKKMs fagseminar 1991]. Oslo

Strømholm, P. 1990: Farvel til fortida. Idéhistorie og vår livsverden. Oslo

Hans Egede-Nissen er cand.philol. i kunsthistorie med en oppgave om Sverre Fehns innsatser som utstillingsarkitekt.

Adr. Damstredet 5, N-0177 Oslo

E-post: hansege@online.no 